Vol. 6, No. 1, Maret 2020

\title{
PENGGUNAAN SCSS (SUZUKI COSTUMER SATISFACTION SURVEY) \\ UNTUK MENGUKUR TINGKAT KEPUASAN PELANGGAN DALAM \\ MENINGKATKAN PENJUALAN SUZUKI MOBIL
}

\author{
SAMUEL BANUREA
}

STIE Madani Balikpapan

Email : samuelbanurea@gmail.com

\begin{abstract}
Abstrak
PT. Suzuki Indomobil Sales sebagai Agen Tunggal Pemegang Merk (ATPM) Suzuki di Indonesia sebagai sebuah perusahaa yang mengejar keuntungan atas kegiatan yang dijalankannya harus pula memperhatikan pelayanan yang diberikan agar kepuasan pelanggan dapat tercapai. Suzuki menganggap pelayanan adalah aktivitas yang dilakukan seseorang atau sekelompok orang dengan landasan faktor material melalui sistem, prosedur, dan metode tertentu dalam rangka memenuhi kebutuhan orang lain sesuai dengan haknya. Hal ini menjelaskan bahwa pelayanan adalah suatu bentuk sistem, prosedur atau metode tertentu yang diberikan kepada orang lain dalam hal ini pelanggan agar kebutuhan pelanggan tersebut dapat terpenuhi sesuai dengan harapan mereka.

Pelayanan yang bertujuan memperoleh kepuasan pelanggan bukanlah suatu yang mudah dilakukan. Sering didapati masalah-masalah dalam pengelolaan pelayanan perusahaan dan ketidakberhasilan memuaskan sebagian pelanggan mereka. Masalah atau persoalan yang biasa dihadapi baik oleh perusahaan maupun pelanggan berkaitan dengan mutu layanan yang diberikan perusahaan kepada pelanggannya adalah sistem layanan yang birokratis, berbelit-belit, dan tidak jelas, kedua, sumber daya manusia perusahaan yang masih belum menyadari arti pentingnya pelanggan bagi keberhasilan perusahaan, pengetahuan dan kemampuan yang kurang, sikap dan perilaku yang belum baik.

PT. Suzuki Indomobil Sales sebagai Agen Tunggal Pemegang Merk (ATPM) Suzuki di Indonesia menyatakan dari hasil penelitian tentang pengukuran tingkat kepuasan pelanggan bahwa tingkat kepuasan pelanggan dipengaruhi secara positif oleh dimensi pelayanan (dimensi empati, kecepat-tanggapan, dan jaminan). Ketiga hal ini menjadi indikator untuk menentukan apakah tingkat pelayanan sudah mampu mencapai tingkat kepuasan pelanggan. Empati menunjukkan kepedulian pihak perusahaan kepada pelanggan atau calon pelanggan, kecepat tanggapan merupakan daya kemampuan memahami apa yang diinginkan pelanggan dari perusahaan, dan jaminan sebagai bentuk kepastian yang diperoleh pelanggan setelah
\end{abstract}


dilakukan transaksi pembelian. Komitment Suzuki ini dibuktikan dengan melaksanakan SCSS (Suzuki Costumer Satisfaction Survey) untuk mengetahui tingkat Pelaksanaan kepuasan pelanggan yang dilakukan oleh team sales terhadap konsumennya.

\section{PENDAHULUAN}

Dari keseluruhan kegiatan yang dilakukan oleh sebuah perusahaan pada akhirnya akan bermuara pada nilai yang akan diberikan oleh pelanggan mengenai kepuasan yang dirasakan. Kepuasan merupakan tingkat perasaan dimana seseorang menyatakan hasil perbandingan atas kinerja produk (jasa) yang diterima dan yang diharapkan. Dalam era globalisasi ini, perusahaan akan selalu menyadari pentingnya faktor pelanggan. Oleh karena itu, mengukur tingkat kepuasaan para pelanggan sangatlah perlu, walaupun hal tersebut tidaklah semudah mengukur berat badan atau tinggi badan pelangggan yang bersangkutan.

Banyak manfaat yang diterima oleh perusahaan dengan tercapainya tingkat kepuasaan pelanggan yang tinggi. Tingkat kepuasaaan pelanggan yang tinggi dapat meningkatkan loyalitas pelanggan dan mencegah perputaran pelanggan, mengurangi sensitivitas pelanggan terhadap harga, mengurangi biaya kegagalan pemasaran, mengurangi biaya operasi yang diakibatkan oleh meningkatnya jumlah pelanggan, meningkatkan efektivitas iklan, dan meningkatkan reputasi bisnis.

Ada tiga dampak yang berpengaruh langsung dalam kepuasan pelanggan dan dijadikan dasar bagi Suzuki kenapa perlunya mengukur tingkat kepuasan pelanggannya yang sering disebut tiga area keprimaan dalam organisasi PT. Suzuki Indomobil Sales sebagai Agen Tunggal Pemegang Merk (ATPM) Suzuki di Indonesia yaitu:

1. Business Excellence dengan bagusnya kualitas pelayanan maka akan meningkatkan keuntungan dan pertumbuhan usaha

2. Operational Excelence dengan bagusnya kualias pelayanan maka akan menciptakan operational excellence yang betujuan mencipakan sumbedaya manusia yang poduktiv, efektif dan eisien 
3. Service Excelence dengan bagusnya kualitas pelayanan akan membangun positive experience dan kepuasan pada konsumen

ketiga hal ini saling berkaitan satu dengan lainnya dan memiliki pengaruh yang signifikan satu dengan lainnya, suzuki menganggap hal ini perlu dalam meningkatkan keuntungan dan pertumbuhan usahanya

Gambar 2.

Tiga Area Keprimaan Dalam Organisasi

$\$$ SUzukn

TIGA AREA KEPRIMAAN DALAM ORGANISASI

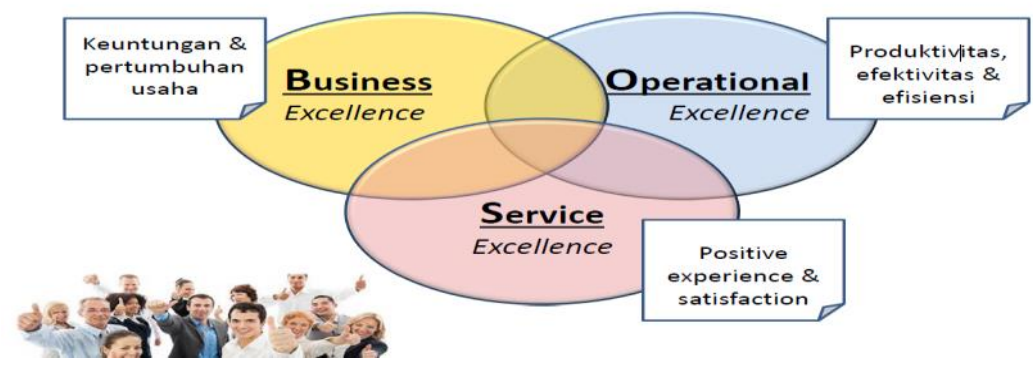

Perilaku konsumen adalah sebuah kegiatan yang berkaitan erat dengan proses pembelian suatu Kendaraan. Suzuki sebagai pemasar merasa perlu meningkakan kepuasan pelanggan seiring dengan perilaku konsumen ini. Mulai proses, hingga cara mengetahui masalah-masalah konsumen yang sering dihadapi ketika melakukan pembelian. Perilaku konsumen merupakan hal-hal yang mendasari konsumen untuk membuat keputusan pembelian. Ketika memutuskan akan membeli suatu barang atau produk, tentu konsumen selalu memikirkan terlebih dahulu barang yang akan Anda beli. Mulai dari harga, kualitas, fungsi atau kegunaan barang tersebut, dan lain sebagainya. Kegiatan memikirkan, mempertimbangkan, dan mempertanyakan barang sebelum membeli merupakan atau termasuk ke dalam perilaku konsumen. Seperti yang telah dijelaskan sebelumnya, perilaku konsumen sangat erat kaitannya dengan pembelian dan penjualan barang dan jasa. Tentu sebagai konsumen, Anda tidak ingin salah membeli suatu produk atau jasa, maka dari itu perilaku konsumen diperlukan. suzuki sebagai pemasar menganggap kepuasan pelanggan dimulai sejak salesman 
bertemu dengan calon pelanggan, maka salesman wajib mengetahui tentang perilaku pembelian konsumen sehingga tau cara menempatkan pelayanan terbaik.

Pada dasarnya kepuasan pelanggan dan ketidakpuasan pelanggan atas produk akan berpengaruh pada pola perilaku selanjutnya. Hal ini ditunjukkan pelanggan setelah terjadi proses pembelian. Apabila pelanggan merasa puas, maka dia akan menunjukkan besarnya kemungkinan untuk kembali dan memebeli produk yang sama. Pelanggan yang puas juga cenderung akan memberikan referensi yang baik terhadap produk kepada orang lain. Tidak demikian dengan seorang pelanggan yang tidak puas. Pelanggan yang tidak puas dapat melakukan tindakan pengembalian produk, atau secara ekstrem bahkan dapat mengajukan gugatan terhadap perusahaan melalui seorang pengacara. Hal tersebut haruslah dapat diantisipasi oleh perusahaan, karena seorang pelanggan yang tidak puas dapat merusak citra perusahaan. Perusahaan harus memilik cara untuk meminimalkan jumlah pelanggan yang tidak puas setelah proses pembelian terjadi.

\section{Gambar 2.}

Tindakan dalam mengatasi keluhan pelanggan
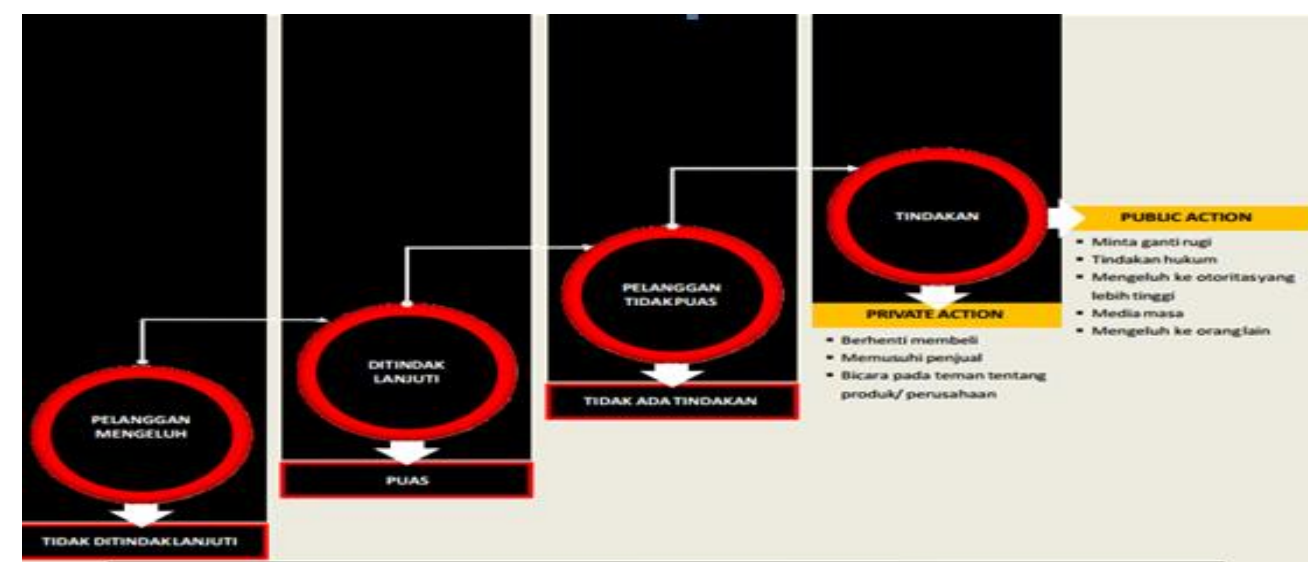

Suatu Tingkat Kepuasan pelanggan akan cepat menyebar di masyarakat hal ini akan menjadi penentu terhadap perusahaan dalam naik turunnya trend penjualan perusahaan tersebut, perkembangan penyebaran informasi terhadap suatu tingkat kepuasan pelanggan yang dilakukan perusahaan saat ini terus berubah dimana di era tahun 1975 apabila terjadi kasalahan pelayanan maka 
informasi ini akan tersebar hanya terbatas kepada orang orang tertentu saja, kemudian tahun 1983 akan berkembang ke 10 orang atau lebih akibat sudah mulai berkembangnya media Koran di jaman ini, diera tahun 2002 penyebaran informasi ini akan lebih cepat tersebar akibat masyarakat sudah mulai menggunakan media internet yang daya jangkauannya lebih luas, dan diera saat ini perkembangannya sangat pesat kualitas pelayanan yang dilakukan perusahaan akan sangat cepat tersebar dimasyarakat bahkan penyebarannya bias langsung menjadi viral dimasyarakat.

\section{Gambar 3}

Perubahan penyebaran Kepuasan Pelanggan

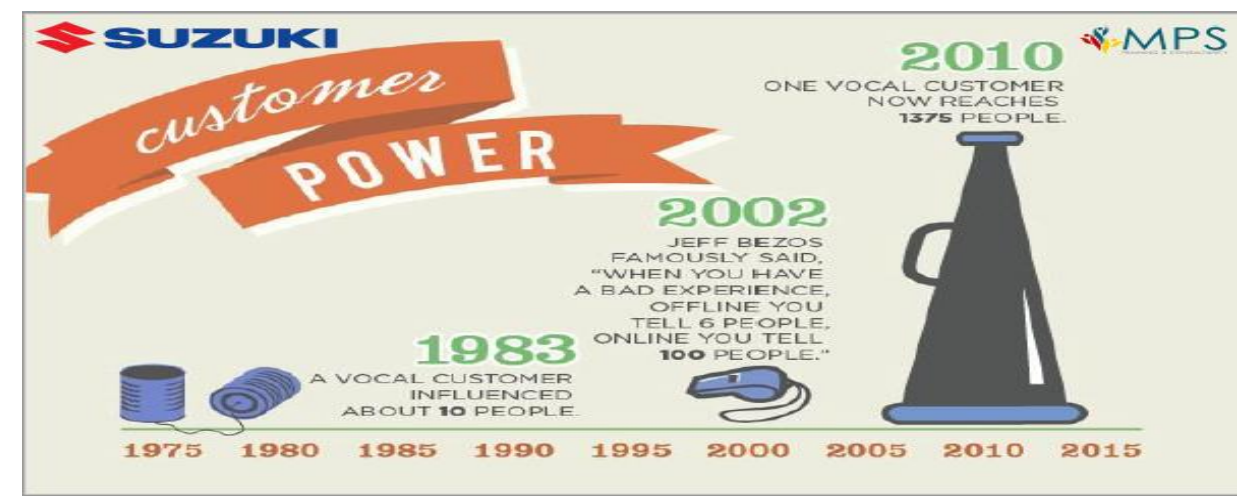

PT. Suzuki Indomobil Sales sebagai Agen Tunggal Pemegang Merk (ATPM) Suzuki di Indonesia menunjukkan kommitmenya dalam meningkatkan kualitas pelayanan dengan menggandeng sebuah lembaga survey independent RAD Research CATI Centre Bandung dalam melaksanakan2 tugas utamanya SCSS (Suzuki Costumer Satisfaction Survey) yang berguna untuk mengukur tingkat kepuasan pelanggan. Hasil Pelaksanaan survey kepuasan pelanggan dapat dilihat secara langsung oleh para dealer dealer setempat secara up date tentang tingkat kepuasan pelanggan dengan cukup melihat di web http://scss4w.com/login seperti tampak pada gambar di bawah ini. 
Gambar 1.1.

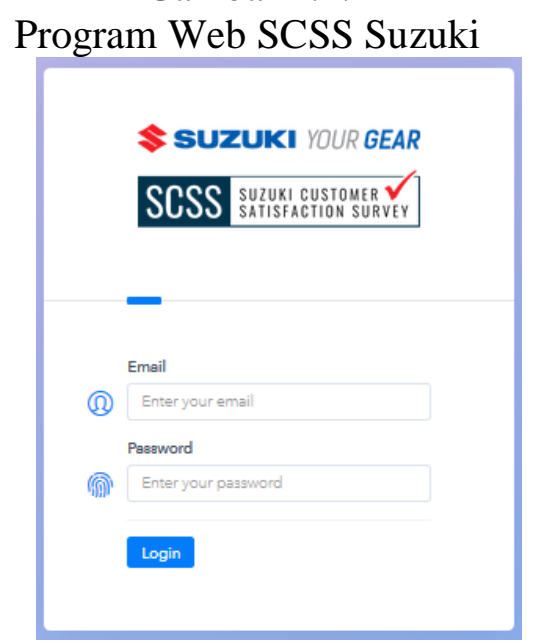

Pelaksanaan SCSS ini bersifat local dengan mengambil sampel sebanyak 30 konsumen per quartal ditujukan khusus untuk pembeli Suzuki passenger karena dianggap pembeli ini sangat kritis terhadap pembelian unit dan dapat diukur tingkat kemampuan pelanggannya. Setiap delaer local diwajibkan menggunakan web http://scss4w.com/login akan di berikan account dan password sendiri dengan harapan dapat memonitoring sendiri implementasi pelaksanaan kepuasan pelanggan oleh team penjualan kekonsumennya, dan apabila ditemukan komplain bias segera ditangani.

\section{KERANGKA TEORI}

\section{SCSS (Suzuki Costumer Satisfaction Survey)}

SCSS (Suzuki Costumer Satisfaction Survey) adalah survey yang dilakukan kepada pembeli semua varian unit Suzuki, secara umum yang dimaksud dengan SCSS (Suzuki Costumer Satisfaction Survey) ADALAH Survey kepuasan pelanggan mengenai pengalamannya ketika membeli mobil Suzuki dari awal pertama bertemu Wiraniaga hingga proses serah terima kendaraan. Suzuki sudah berkomitment menjalankan survei terhadap kepuasan pelanggannya dengan memiliki 2 tujuan (tujuan Utama dan Tujuan Spesifik)

\section{Tujuan Utama SCSS (Suzuki Costumer Satisfaction Survey)}

Tujuan Utama dalam melaksanakan SCSS (Suzuki Costumer Satisfaction Survey) adalah untuk Melakukan evaluasi tingkat kepuasan pelanggan dari pelayanan Dealer Suzuki guna meningkatkan kepuasan pelanggan dengan 
mengidentifikasi kebutuhany ang tidak terpenuhi dan apa saja menjadi faktor ketidakpuasan.

\section{Tujuan Spesifik}

Sedangkan tujuan Spesisifik dalam menjalankan kegiatan SCSS (Suzuki Costumer Satisfaction Survey) pada konsumen pembeli Suzuki adalah

- Mengetahui tingkat kepuasan pada seluruh proses penjualan di Dealer Suzuki.

- Mengetahui area yang menjadi kelemahan Dealer dan melakukan monitoring dari waktu ke waktu

\section{Kepuasan konsumen}

Kepuasan Konsumen adalah tingkat perasaan konsumen setelah membandingkan antara apa yang dia terima dan harapannya (Umar, 2005:65). Seorang pelanggan, jika merasa puas dengan nilai yang diberikan oleh produk atau jasa, sangat besar kemungkinannya menjadi pelanggan dalam waktu yang lama.

Menurut Philip Kotler dan Kevin Lane Keller yang dikutip dari buku Manajemen Pemasaran mengatakan bahwa Kepuasan Konsumen adalah perasaan senang atau kecewa seseorang yang muncul setelah membandingkan kinerja (hasil) produk yang dipikirkan terhadap kinerja yang diharapkan (Philip Kotler 2007:177).

Memuaskan kebutuhan konsumen adalah keinginan setiap perusahaan. Selain faktor penting bagi kelangsungan hidup perusahaan, memuaskan kebutuhan konsumen dapat meningkatkan keunggulan dalam persaingan. Konsumen yang puas terhadap produk dan jasa pelayanan cenderung untuk membeli kembali produk dan menggunakan kembali jasa pada saat kebutuhan yang sama muncul kembali dikemudian hari. Hal ini berarti kepuasan merupakan faktor kunci bagi konsumen dalam melakukan pembelian ulang yang merupakan porsi terbesar dari volume penjualan perusahaan. 


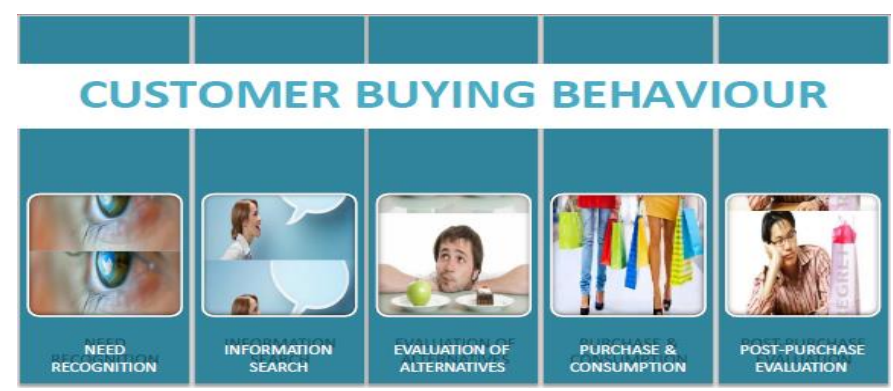

Perilaku konsumen dilakukan berdasarkan suatu proses sebelum dan sesudah seorang konsumen melakukan proses pembelian suatu barang maupun jasa. Dalam perilaku konsumen tersebut, seorang pembeli akan melakukan penilaian yang kemudian pada akhirnya akan mempengaruhi proses pengambilan keputusannya atas pembelian barang atau jasa tersebut. Berikut beberapa tahapan pengambilan keputusan seorang konsumen :

\section{Pengenalan Masalah.}

Biasanya seorang konsumen melakukan pembelian atas dasar kebutuhan atau untuk menyelesaikan keperluan, masalah dan kepentingan yang dihadapi. Jika tidak ada pengenalan masalah terlebih dahulu, maka konsumen juga tidak akan tahu produk mana yang harus dibeli.

\section{Pencarian Informasi.}

Setelah mengetahui permasalahan yang dialami, maka pada saat itu seorang konsumen akan aktif mencari tahu tentang bagaimana cara penyelesaian masalahnya tersebut. Dalam mencari sumber atau informasi, seseorang dapat melakukannya dari diri sendiri (internal) maupun dari orang lain (eksternal) seperti masukan, sharing pengalaman, dan lain sebagainya.

\section{Mengevaluasi Alternatif.}

Setelah konsumen mendapatkan berbagai macam informasi yang dibutuhkan dalam pengambilan keputusan, maka hal selanjutnya yang dilakukan oleh konsumen tersebut adalah mengevaluasi segala alternatif keputusan maupun informasi yang diperoleh. Hal itu lah yang menjadi landasan dalam mengatasi permasalahan yang dihadapi. 


\section{Keputusan Pembelian.}

Proses selanjutnya setelah melakukan evaluasi pada alternatif-alternatif keputusan yang ada adalah konsumen tersebut akan melalui proses yang disebut dengan keputusan pembelian. Waktu yang diperlukan dalam proses pengambilan keputusan ini tidak sama, yaitu tergantung dari hal-hal yang perlu dipertimbangkan dalam proses pembelian atau pengambilan keputusan tersebut.

\section{Evaluasi Pasca-Pembelian.}

Proses lanjutan yang biasanya dilakukan seorang konsumen setelah melakukan proses dan keputusan pembelian adalah mengevaluasi pembeliannya tersebut. Evaluasi yang dilakukan mencakup pertanyaan-pertanyaan mendasar seperti apakah barang tersebut sudah sesuai dengan harapan, sudah tepat guna, tidak mengecewakan, dan lain sebagainya. Hal ini akan menimbulkan sikap kepuasan dan ketidakpuasan barang oleh konsumen, mengecewakan dan tidak mengecewakan. Hal tersebut akan berdampak pada pengulangan pembelian barang atau tidak. Jika barang memuaskan dan tidak mengecewakan, maka konsumen akan mengingat merk produk tersebut sehingga akan terjadi pengulangan pembelian di masa mendatang. Namun jika barang tidak memuasakan dan mengecewakan, maka konsumen juga akan mengingat merk barang tersebut dengan tujuan agar tidak mengulang kembali membeli barang tersebut di masa yang akan datang.

\section{METODOLOGI PENELITIAN}

Dalam kasus kali ini, metodologi yang digunakan untuk membantu analisa permasalahan ini adalah metodologi wawancara/ interview. Wawancara/ interview lebih efektif dalam membantu analisa permasalahan ini, karena kasus permasalahan ini dialami langsung oleh konsumen, sehingga dengan menggunakan metode wawancara/ interview, penulis mendapatkan informasi yang akurat dari konsumen. 


\section{Metode Survey Kuantitatif}

Survei dilakukan terhadap 30 orang konsumen khusus pembeli Suzuki passenger karena dianggap pembeli untuk type ini lebih kritis dan peduli terhadap kepuasan pelanggan dibandingkan pembeli komersial, adapun ketentuan sirvei yang dilakukan adalah:

- Menggunakan CATI (Computer Assisted Telephone Interview)

- Daftar responden diambil dari data Faktur penjualan unit suzuki

- Dilakukan secara Screening survey :

- Konsumen yang di survey adalah H+9 setelah Delivery

- Konsumen yang disurvei Wajib ikut serta dalam seluruh proses pembelian mobil

- Durasi interview : 15-20 menit

\section{Kala penilaian Survei Kepuasan Pelanggan}

Ada 2 skala pengukuran kepuasan pelanggan yang dilakukan oleh lembaga survey yang khusus ditunjuk oleh PT. Suzuki Indomobil Sales

\section{Skala ukuran jawaban 1-10}

Konsumen yang disurvei akan diberikan jawaban dari angka 1 sampai dengan 10 yang terdiri atas 21 pertanyaan pada 6 Faktor SSI (Sales Satisfaction Index) dengan harapan akan menghasilkan nilai skor kepuasan SSI.

\section{Skala Ukuran Ya atau Tidak}

Untuk jawaban Ya atau tidak menunjukkan Implementasi SOP yang wajib dilakukan oleh salesman kepada pelanggannya Seluruh jawaban responden untuk setiap pertanyaan SOP dihitung \% yang menjawab "YA" saja.

\section{Periode Pelaksanaan SCSS (Suzuki Costumer Satisfaction Survey)}

Dalam pelaksanaannya survey dilakukan $4 \mathrm{x}$ periode survey per tahun kepuasan konsumen dimana setiap wave terdapat 3 bulan lama waktunya . Hasil final akan disimpulkan pada awal bulan pada wave berikutnya dengan 
mengirimkan report hasil final per wave yang bisa di upload di web http://scss4w.com/login

Gambar 2.1

Periode pelaksanaan SCSS

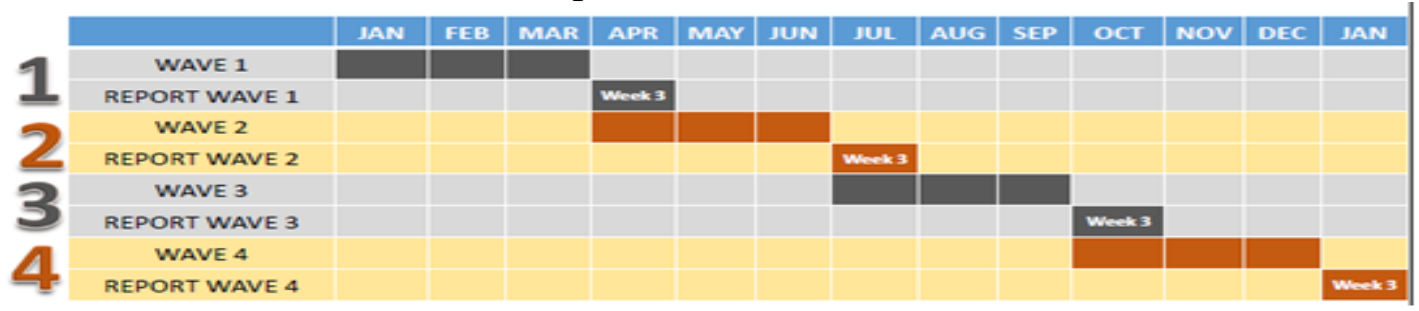

\section{Parameter SCSS dari 6 Faktor SSI (Sales Satisfaction Index)}

Untuk mendapatkan ukuran kepuasan pelanggan maka Suzuki membuat 6 standard pertanyaan yang akan diberikan kepada konsumen yang sering disebut SSI (Sales Satisfaction Index), adapun penjelasan pertanyaan yang diajukan untuk masing masing factor adalah:

Gambar 2.2

Parameter dan Bobot

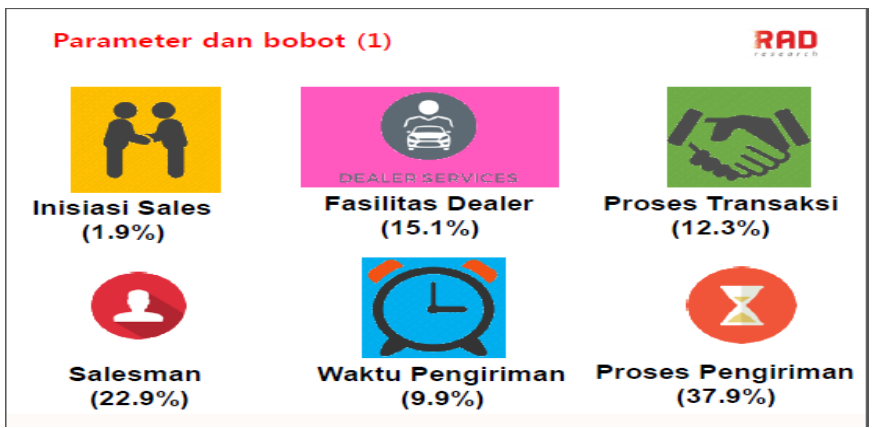

A. Sales Initiation dengan bobot $1.9 \%$

1. Pertanyaan yang akan diajukan ada 4 untuk Sales Initation Skala ukuran jawaban 1-10

a. Lama waktu menunggu untuk disapa/disambut di dealer

b. Cara salesman menjelaskan fitur, kelebihan, dan manfaat dari mobil

c. Cara salesman memberikan contoh penggunaan fitur/fungsi mobil 
d. Menjawab semua pertanyaan sebelum memutuskan pembelian

2. Pertanyaan Ya atau Tidak menunjukkan implementasi SOP pada Sales Inititation adalah
a. Disambut ketika pertama kali masuk ke dealer
b. Menawarkan minuman/tersedia minuman dishowroom
c. Salesman memperkenalkan diri
d. Menawarkan test drive
e. Salesman menemani melakukan tes drive
f. Memberikan contoh penggunaan fitur/fungsi mobil sewaktu test drive
g. Menunjukan fitur-fitur pada mobil yang sedang dipajang
h. Menunjukan katalog/brosur
i. Sales memberikan contoh penggunaan fitur/fungsi mobil

B. Dealer Facility dengan bobot $15.1 \%$

1. Pertanyaan yang akan diajukan ada 4 untuk Dealer Facility Skala ukuran jawaban 1-10

a. Kemudahan lokasi (lokasi mudah dijangkau, kemudahan masuk/keluar dealer, fasilitas parkir)

b. Tampilan fasilitas dealer (Tata letak/ layout, desain)

c. Banyaknya jenis pilihan mobil yang tersedia di dealer

d. Kenyamanan \& kebersihan di showroom

2. Pertanyaan Ya atau Tidak menunjukkan implementasi SOP pada Dealer Facility adalah

a. Terdapat toilet yang bersih dan terawat

C. Deal Proses dengan bobot $12.3 \%$

1. Pertanyaan yang akan diajukan ada 4 untuk Deal Proses Skala ukuran jawaban 1-10

a. Kemudahan mencapai kesepakatan untu ktransaksi final

b. Kejelasan tentang dokumen pembelian dan pembayaran yang diterangkan

c. Ketepatan waktu dalam melengkapi proses administrasi pembelian 
d. Perbandingan harga yang dibayar dengan harapan

a. Pertanyaan Ya atau Tidak menunjukkan implementasi SOP pada Deal Proses adalah

a. Dealer tidak menarik biaya untuk hal yang gratis/merubah harga yang dijanjikan

D. Sales Person dengan bobot $22.9 \%$

1. Pertanyaan yang akan diajukan ada 4 untuk Sales Person Skala ukuran jawaban 1-10

a. Sopan dan bersahabat

b. Memenuhi komitmen (janji yang dibuat)

2. Pertanyaan Ya atau Tidak menunjukkan implementasi SOP pada Sales Person adalah

a. Salesman berpenampilan rapi dan bersih

b. Salesman menanyakan penggunaan dan kebutuhan mobil

c. Salesman meluangkan waktu yang cukup untuk konsumen

E. Delivery Time dengan bobot $9.9 \%$

1. Pertanyaan yang akan diajukan ada 4 untuk Delivery Time Skala ukuran jawaban 1-10

a. Lama waktu yang dibutuhkan untuk mengantarkan mobil

b. Informasi mengenai waktu pengiriman mobil

c. Mengantarkan mobil sesuai tanggal dan waktu yang dijanjikan

2. Pertanyaan Ya atau Tidak menunjukkan implementasi SOP pada Delivery Time adalah

a. Salesman mengantarkan mobil kepada konsumen

b. Tempat pengiriman mobil sesuai dengan keinginan konsumen

F. Deliveri Proses dengan bobot $37.9 \%$

1. Pertanyaan yang akan diajukan ada 4 untuk Deliveri Proses Skala ukuran jawaban 1-10

a. Kondisi/kebersihan mobil baru

b. Waktuyang dibutuhkan ketika proses serah terima mobil

c. Kelengkapan dari penjelasan (buku panduan, fitur, dll) 
d. Kemampuan menjawab pertanyaan saat proses pengiriman/ serah terima

2. Pertanyaan Ya atau Tidak menunjukkan implementasi SOP pada Delivery Time adalah
a. Fitur kendaraan sesuai dengan yang dijanjikan ketika transaksi
b. Konsumen diberikan kartu nama atau diperkenalkan petugas bengkel secara langsung
c. Menerima ucapan terima kasih atas pembelian mobil
d. Jumlah bahan bakar yang layak
e. Ada acara special saat proses pengiriman/serah terima
f. Dihubungidealer1 hari setelah proses pengiriman
g. Dihubungi dealer 3 hari setelah proses pengiriman
h. Mendapatkan penjelasan fitur keamanan mobil saat proses pengiriman
i. Mendaptkan penjelasan pengoperasian fitur saat proses pengiriman
j. Mendapatkan penjelasan cakupan garansi saat proses pengiriman
k. Mendapatkan penjelasan jadwal perawatan saat proses pengiriman

\section{Improvement Performance Analysis}

Untuk penelitian hasil penelitian wawancara bobot nilai atribut dan implementasi SOP ini tersebut akan dihitung dan dalam mengambil kesimpulan maka menggunakan skala prioritas agar mengetahui mana factor factor yang menjadi prioritas utama dilakukan perbaikan kedepan, skala ini memeiliki 4 skala

1. Dipertahankan nilai tambah adalah Tingkat Kepentingan Rendah, namun Kinerja Dealer sudah baik yaitu sudah di atas Target

2. Dipertahankan - Harus Dimiliki adalah Tingkat Kepentingan Tinggi, dan Kinerja Dealer sudah baik yaitu sudah di atas Target

3. Prioritas Berikutnya adalah Tingkat Kepentingan Rendah, dan Kinerja Dealer belum baik yaitu masih di bawah Target

4. Prioritas Utama adalah Tingkat Kepentingan Tinggi, dan Kinerja Dealer belum baik yaitu masih di bawah Target 


\section{Gambar 2.3}

Skala Prioritas

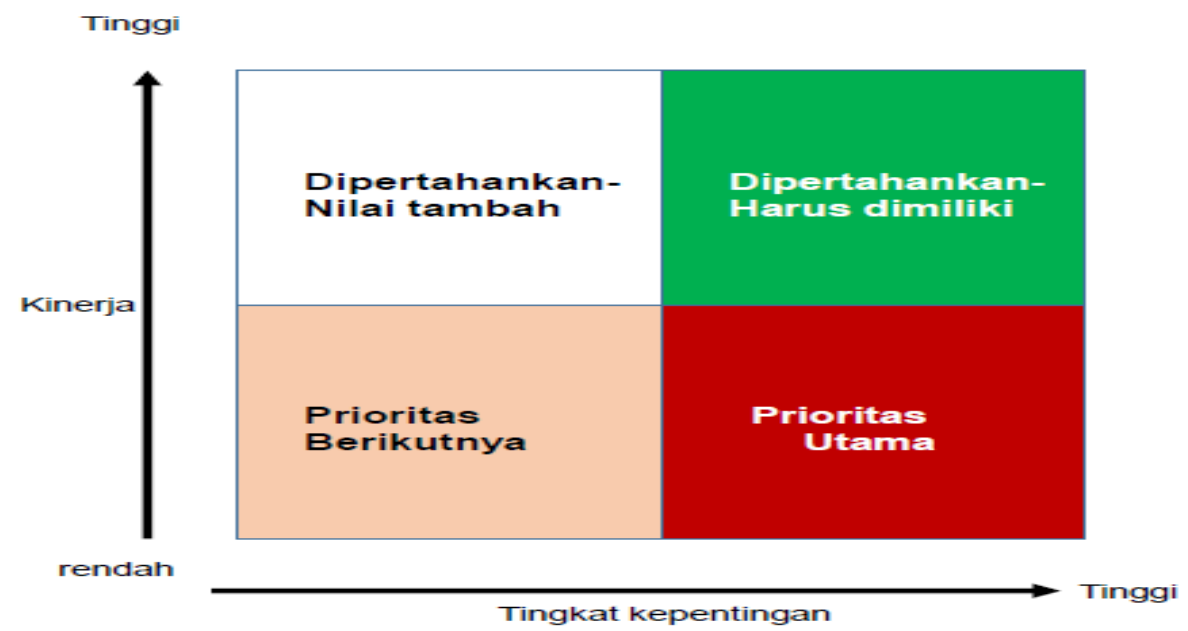

Keempat aspek ini memiliki makna sebagai berikut:

- Prioritas Utama : Aspek-aspek yang sangat mempengaruhi terhadap tingkat kepuasan konsumen akan tetapi kinerja dealer dalam aspek tersebut dibawah rata-rata sehingga menjadi prioritas utama untuk segera diperbaiki.

- Prioritas Berikutnya : Aspek-aspek dengan tingkat kepentingan lebih rendah yang mempengaruhi tingkat kepuasan konsumen dan kinerja dealer pada aspek tersebut masih dibawah rata-rata sehingga menjadi prioritas berikutnya untuk diperbaiki.

- Dipertahankan - Harus dimiliki : Aspek-aspek yang sangat mempengaruhi terhadap tingkat kepuasan konsumen dan kinerja dealer pada aspek tersebut sudah diatas rata-rata sehingga perlu dipertahankan.

- Dipertahankan - Nilai tambah : Aspek-aspek dengan tingkat kepentingan yang rendah tetapi dapat memberikan nilai tambah jika dimiliki dan kinerja dealer pada aspek tersebut saat ini sudah diatas rata-rata sehingga perlu dipertahankan. 


\section{HASIL DAN PEMBAHASAN}

\section{Karateristik Responden}

SALES SATISFACTION INDEX (SSI) adalah Mengukur kepuasan konsumen pada pre-sales, sales, dan proses pengiriman pada pembeli mobil Suzuki aru (hanya mobil penumpang) dalam 3 bulan terakhir diseluruh Dealer Suzuki di Indonesia. Dalam penelitian di WAVE 32016 periode Oct-Dec 2016 hasil penelitian untuk wilayah Kalimantan Timur

Gambar 4.1

\section{Profil Konsumen 1}

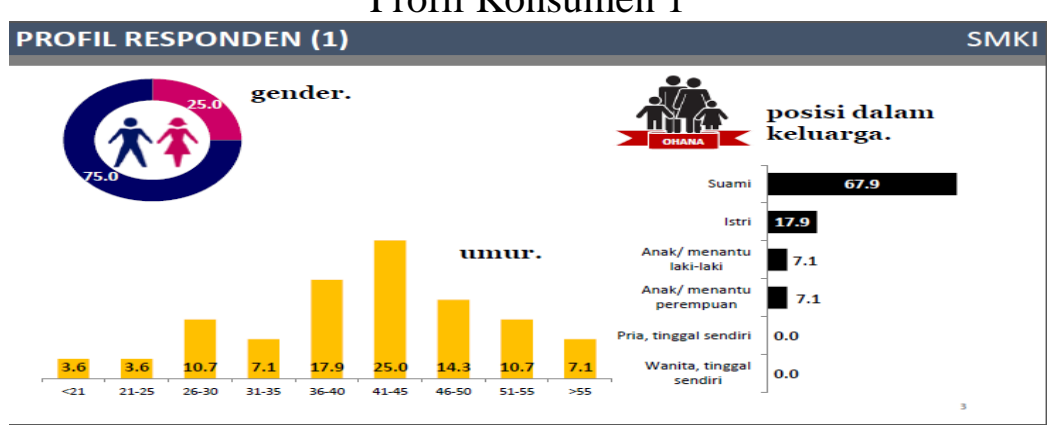

Berdasarkan gambar 4.1 Dari profil konsumen Usia yang paling dominan adalah umur 41-45 tahun kemudian diikuti 36-40 tahun dan terakhir usia < 21 tahun. Untuk posisi dalam keluarga dalam keputusan pembelian mobil dominan adalah Suami $67.9 \%$ kemudian istri $17.9 \%$

Gambar 4.2

Profil Konsumen 2

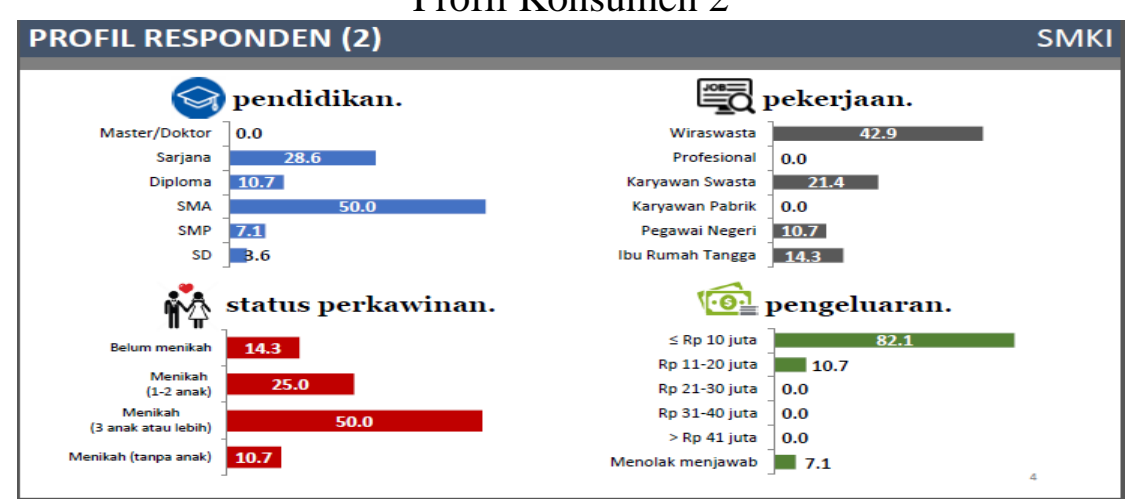

Berdasarkan gambar 4.2 Dari profil konsumen untuk tingkat pendidikan dominan adalah SMA $50 \%$ kemudian diikuti sarjana 28.6\%, status perkawinan dominan adalah menikah 3 anak atau lebih diangka 50\% dan kemudian diikuti 
menikah (1-2 anak) sebanyak 25\%, Untuk pekerjaan dominan pembeli adalah Wiraswasta sebanyak $42.9 \%$ kemudian diikuti karyawan swasta $21.4 \%$.

\section{Hasil penelitian}

Pelanggan Suzuki yang baru membeli mobil penumpang baru merek Suzuki dari dealer resmi dalam kurun waktu 3 bulan terakhir. Dengan menggunakan Metode survei Kuantitatif, Menggunakan CATI (Computer Assisted Telephone Interview), Bertempat dikantor RAD Research, dimana Daftar konsumen yang di survey adalah data yang disediakan oleh Team Suzuki, maka ditemukan hasil berikut.

\section{Nilai Total SSI dan Faktor-Faktor SSI Kalimantan Timur W3 2016}

Berdasarkan hasil penelitian di wave 3 (oct-dec 2016) ditemukan nilai SCSS untuk wilayah Kalimantan Timur Nilai Total SSI dan Faktor-Faktor SSI Kalimantan Timur W3 2016adalah sebagai berikut:

Gambar 4.3

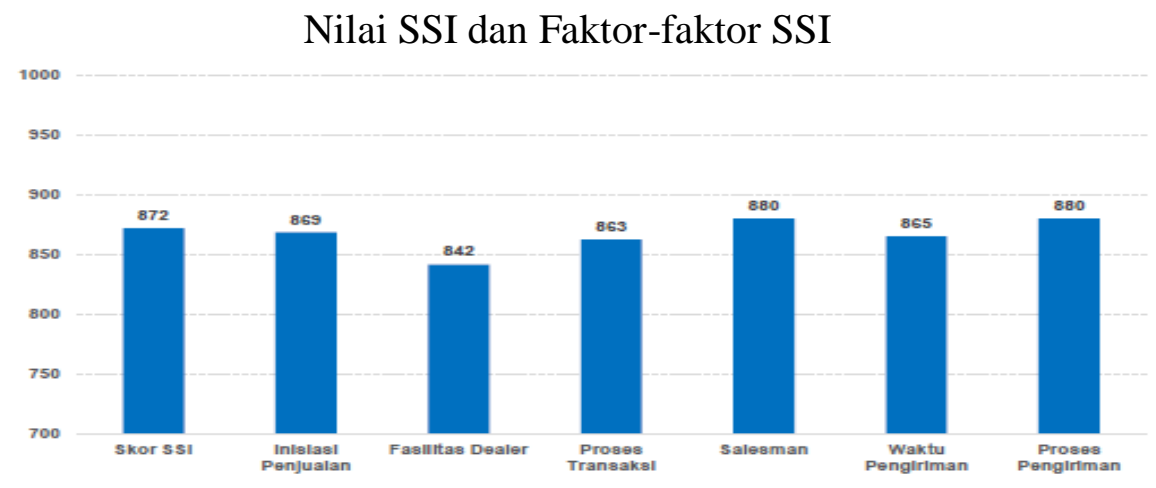

Dari hasil penelitian wave 32016 ditemukan nilai skor SSI sebesar 872 poin, Nilai dari inisisasi penjualan sebesar 869, fasilitas dealer sebesar 842, proses transaksi sebesar 863 , salesman sebesat 880 , waktu pengiriman sebesar 865 dan proses pengiriman sebesar 880 .

Kinerja Kinerja SSI berdasarkan atribut-atribut Kalimantan Timur W3 2016

Berdasarkan hasil penelitian di wave 3 (oct-dec 2016) ditemukan nilai SCSS untuk wilayah Kalimantan Timur Kinerja SSI berdasarkan atribut-atribut Kalimantan Timur W3 2016 adalah sebagai berikut: 
Gambar 4.3

Nilai Kinerja SSI dan Faktor-faktor SSI 1

\begin{tabular}{|l|c|c|c|}
\hline \multicolumn{1}{|c|}{ ATRIBUT } & W1'16 & W2'16 & W3'16 \\
\hline INISIASI SALES & $\mathbf{8 8 1}$ & $\mathbf{8 6 9}$ & $\mathbf{8 6 9}$ \\
\hline Lama waktu menunggu untuk disapa/disambut di dealer & 9,97 & 10,00 & 10,00 \\
\hline $\begin{array}{l}\text { Cara salesman menjelaskan fitur, kelebihan, dan manfaat dari mobil } \\
\text { (termasuk informasi mengenai para pesaing) }\end{array}$ & 8,53 & 8,60 & 8,43 \\
\hline Mendemonstrasikan mobil & 9,00 & 8,52 & 8,67 \\
\hline $\begin{array}{l}\text { Menjawab semua pertanyaan bpk/ibu sebelum bpk/ibu memutuskan } \\
\text { pembelian }\end{array}$ & 8,70 & 8,70 & 8,71 \\
\hline FASILITAS DEALER & 865 & 828 & 842 \\
\hline $\begin{array}{l}\text { Kemudahan Iokasi (Iokasi mudah dijangkau, kemudahan masuk/keluar } \\
\text { dealer, fasilitas parkir dll..) }\end{array}$ & 8,77 & 8,61 & 8,71 \\
\hline Tampilan fasilitas dealer (Tata letak/ layout, desain, kebersihan, dII). & 8,93 & 8,50 & 8,57 \\
\hline Banyaknya jenis pilihan mobil yang tersedia di dealer (warna, model, dIII) & 8,33 & 7,61 & 7,71 \\
\hline $\begin{array}{l}\text { Kemudahan untuk melihat mobil di showroom (mobil dipajang di tempat } \\
\text { yang mudah dicapai, rapi, dll) }\end{array}$ & 9,07 & 8,75 & 8,86 \\
\hline Kenyamanan \& kebersihan di showroom & 8,80 & 8,71 & 8,52 \\
\hline PROSES TRANSAKSI & 876 & 847 & 863 \\
\hline $\begin{array}{l}\text { Seberapa mudah bpk/ibu dan dealer mencapai kesepakatan untuk } \\
\text { transaksi final (harga, jangka waktu pinjaman, aksesoris, pilihan, dII) }\end{array}$ & 8,83 & 8,37 & 8,71 \\
\hline $\begin{array}{l}\text { Kejelasan tentang semua dokumen pembelian dan pembayaran yang } \\
\text { diterangkan }\end{array}$ & 8,77 & 8,37 & 8,76 \\
\hline $\begin{array}{l}\text { Ketepatan waktu dalam melengkapi proses administrasi pembelian } \\
\text { (termasuk waktu yang bpk/ibu habiskan untuk menunggu proses } \\
\text { administrasi dimulai) }\end{array}$ & 8,77 & 8,53 & 8,52 \\
\hline Perbandingan harga yang dibayar dengan harapan bpk/ibu & 8,73 & 8,53 & 8,57 \\
\hline
\end{tabular}

Berdasarkan hasil penelitian untuk w3 2016 nilai yang mengalami penurunan dari w2 2016 untuk inisiasi sales, fasilitas dealer dan proses transaksi adalah poin Cara salesman menjelaskan fitur, kelebihan, dan manfaat dari mobil (termasuk informasi mengenai para pesaing) turun dari sebelumnya nilai 8.60 menjadi 8.40. Kenyamanan \& kebersihan di showroom turun dari 8.71 menjadi 8.52, dan atribut Ketepatan waktu dalam melengkapi proses administrasi pembelian (termasuk waktu yang bpk/ibu habiskan untuk menunggu proses administrasi dimulai)turun dari nilai 8.53 menjadi 8.52 .

Gambar 4.4

Nilai Kinerja SSI dan Faktor-faktor SSI 2

\begin{tabular}{|l|c|c|c|}
\hline \multicolumn{1}{|c|}{ ATRIBUT } & W1'16 & W2'16 & W3'16 \\
\hline SALESMAN & 906 & $\mathbf{8 5 8}$ & $\mathbf{8 8 0}$ \\
\hline Pengetahuan Sales dalam menjelaskan produk mobil & 8,87 & 8,43 & 8,62 \\
\hline Sopan dan bersahabat & 9,10 & 9,03 & 8,90 \\
\hline Memenuhi komitmen-komitmen (janji yang dibuat) & 9,07 & 8,53 & 8,76 \\
\hline WAKTU PENGIRIMAN & 888 & 876 & 865 \\
\hline $\begin{array}{l}\text { Lama waktu yang dibutuhkan untuk mengantarkan mobil bpk/ibu } \\
\text { (mulai dari pemesanan hingga pengantaran / serah terima) }\end{array}$ & 8,70 & 8,63 & 8,57 \\
\hline Informasi mengenai waktu pengiriman mobil bpk/ibu & 8,87 & 8,87 & 8,71 \\
\hline $\begin{array}{l}\text { Kemampuan untuk mengantarkan mobil sesuai tanggal/ waktu yang } \\
\text { dijanjikan pada saat pemesanan }\end{array}$ & 9,10 & 8,70 & 8,62 \\
\hline PROSES PENGIRIMAN & 890 & 862 & 880 \\
\hline $\begin{array}{l}\text { Kondisi/kebersihan mobil baru bpk/ibu (bersih, tidak ada penyokan2, } \\
\text { goresan2, dII.) }\end{array}$ & 9,00 & 9,13 & 9,14 \\
\hline $\begin{array}{l}\text { Antusiasme dari staff membuat proses serah terima mobil menjadi } \\
\text { menyenangkan }\end{array}$ & 9,00 & 8,87 & 8,81 \\
\hline $\begin{array}{l}\text { Waktu yang dibutuhkan ketika proses serah terima mobil bpk/ibu } \\
\text { (termasuk menerangkan fitur, buku panduan, dII) }\end{array}$ & 9,00 & 8,87 & 8,81 \\
\hline $\begin{array}{l}\text { Kelengkapan dari penjelasan-penjelasan (mis. buku panduan, fitur-fitur } \\
\text { dll.) }\end{array}$ & 8,73 & 8,43 & 8,76 \\
\hline $\begin{array}{l}\text { Kemampuan menjawab pertanyaan-pertanyaan bpk/ibu saat proses } \\
\text { pengiriman / serah terima }\end{array}$ & 8,90 & 8,67 & 8,76 \\
\hline
\end{tabular}


Berdasarkan hasil penelitian untuk w3 2016 nilai yang mengalami penurunan dari w2 2016 untuk Salesman, waktu pengiriman dan proses pengiriman adalah poin sopan dan bersahabt turun dari 9.03 menjadi 8.90, Lama waktu yang dibutuhkan untuk mengantarkan mobil bpk/ibu (mulai dari pemesanan hingga pengantaran / serah terima) turun dari 8.63 turun menjadi 8.57 , Informasi mengenai waktu pengiriman mobil bpk/ibu turun dari 8.87 menjadi 8.71, Kemampuan untuk mengantarkan mobil sesuai tanggal/ waktu yang dijanjikan pada saat pemesanan turun dari 8.70 menjadi 8.62, Antusiasme dari staff membuat proses serah terima mobil menjadi menyenangkan turun dari 8,87 menjadi 8,81, dan terakhir Waktu yang dibutuhkan ketika proses serah terima mobil bpk/ibu (termasuk menerangkan fitur, buku panduan, dll) turun dari 8,87 menjadi 8,81 .

\section{Kinerja implementasi SOP sales berdasarkan atribut-atribut Kalimantan Timur W3 2016}

Berdasarkan hasil penelitian di wave 3 (oct-dec 2016) ditemukan nilai SCSS untuk wilayah Kalimantan Timur Kinerja implementasi SOP sales berdasarkan atribut-atribut Kalimantan Timur W3 2016:

Gambar 4.5

Nilai implementasi SOP dan Faktor-faktor SSI 1

\begin{tabular}{|c|c|c|c|}
\hline Sales Adherences & \multirow{2}{*}{ พT16 } & \multirow{2}{*}{ W2'16 } & \multirow{2}{*}{ WST 16} \\
\hline Salas Inlakas & & & \\
\hline Disambut ketka pertama kal masuk ke dealer & 86,67 & 100,00 & 100,00 \\
\hline Menawarkan minuman / tersedla minuman dl showroom & 83,33 & 82,14 & 66,67 \\
\hline Salesman menperkenakan dir & 96,67 & 96,67 & 100,00 \\
\hline Menawarkan test drive & 76,67 & 83,33 & 85,71 \\
\hline Salesman menemanl melakukan test drive & 90,91 & 92,86 & 80,00 \\
\hline Mobl test dive dalam kondlsi bersh dan balk & 100,00 & 100,00 & 100,00 \\
\hline Mendemonstrasikan fitur-ntur sewaktu test arive & 33,33 & 100,00 & 80,00 \\
\hline Menunjukan fltur-ntur pada mobll yang sedang dpajang & 93,33 & 86,67 & 100,00 \\
\hline Menunjukan katalog brosur & 96,67 & 96,67 & 100,00 \\
\hline Menjelaskan secara vertal & - & $\cdot$ & $\cdot$ \\
\hline Sales mendemonstraslkan mobl & 76,67 & 90,00 & 71,43 \\
\hline \multicolumn{4}{|l|}{ Fasellitas Dealer } \\
\hline Terdapat bengkel/tempat service pada Dealer & 90,00 & 92,86 & 85,71 \\
\hline Terdapat tolet yang berslh dan terawat & 66,67 & 71,43 & 47,62 \\
\hline \multicolumn{4}{|l|}{ Proese Traneaksi } \\
\hline Dealer tidak menarik blaya untuk hal yang gratis/merubah harga yang d.|an!likan & 3,33 & 96,67 & 100,00 \\
\hline Tidak ada desakan untuk menbel akseson's & 0,00 & 96,67 & 100,00 \\
\hline PIllhan sumber pembiayanan & 20,00 & 30,00 & 28,57 \\
\hline
\end{tabular}


Berdasarkan hasil penelitian untuk w3 2016 nilai yang mengalami penurunan dari w2 2016 untuk inisiasi sales, fasilitas dealer dan proses transaksi adalah poin Menawarkan minuman/ tersedia minuman di showroom turun dari 82.14 menjadi 66,67, Salesman menemani melakukan test drive turun dari 92.86 menjadi 80,00, Mendemonstrasikan fitur-fitur sewaktu test drive turun dari 100, menjadi 80, Sales mendemonstrasikan mobil turun dari 90 menjadi 71.43 poin, Terdapat bengkel/tempat service pada Dealer turun dari 92,86 menjadi 85,71, Terdapat toilet yang bersih dan terawat turun dari 71,43 menjadi 47,62 poin, dan terakhir Pilihan sumber pembiayanan turun dari 30,00 menjadi $28,57 \mathrm{n}$ poin.

Gambar 4.6

Nilai implementasi SOP dan Faktor-faktor SSI 1

\begin{tabular}{|c|c|c|c|}
\hline Sales Adherences & \multirow{2}{*}{ W1'16 } & \multirow{2}{*}{ W2'16 } & \multirow{2}{*}{ WS'16 } \\
\hline Sales Person & & & \\
\hline Salesman berpenamplan rapi dan bersin & 100,00 & 100,00 & 100,00 \\
\hline Salesman menanyakan pernggunaan dan kebutuhan mool & 90,00 & 96,67 & 95,24 \\
\hline Salesman meluangkan waktu yang cukup untuk konsumen & 100,00 & 96,67 & 100,00 \\
\hline \multicolumn{4}{|l|}{ Dellvary Time } \\
\hline Salesman mengantarkan mool kepada konsumen & 40,00 & 96,67 & 90,48 \\
\hline Tempat pengiriman mooll sesual dengan keinginan konsumen & 96,67 & 100,00 & 100,00 \\
\hline Tidak acla desakan untuk mengambil waktu yang tidak sesual & 0,00 & 100,00 & 100,00 \\
\hline \multicolumn{4}{|l|}{ Dallwery Process } \\
\hline Fitur-ntur kendaraan sesual dengan yang dljan|jkan ketka transaks! & 86,67 & 96,67 & 100,00 \\
\hline Konsumen diberikan kartu nama atau dperkenalkan petugas service/bengkel secara langsung & 56,67 & 66,67 & 71,43 \\
\hline Menerima ucapan tenma k3sih atas permbellan mool & 93,33 & 86,67 & 100,00 \\
\hline Jumlah bahan bakar yang layak & 100,00 & 96,67 & 95,24 \\
\hline Ada acara spesial saat proses penginmaniserah terima & 33,33 & 30,00 & 71,43 \\
\hline Dhubung dealer 1 harl setelah proses pengirimanjpengartaran & 50,00 & 63,33 & 71,43 \\
\hline Dhubung dealer 3 har setelah proses pengirimanipengartaran & 46,67 & 53,33 & 47,62 \\
\hline Mendaspatkan penjelassan ntur keamanan mobll & 86,67 & 83,33 & 85,71 \\
\hline Mendapatkan penjelzsan pengoperaslan fitur & 90,00 & 90,00 & 90,48 \\
\hline Mendzpatkan penjel3san cakupan garansl & 93,33 & 86,67 & 85,71 \\
\hline Mendzpatkan penjel3san jacwal perawatan & 96,67 & 96,67 & 100,00 \\
\hline
\end{tabular}

Berdasarkan hasil penelitian untuk w3 2016 nilai yang mengalami penurunan dari w2 2016 untuk Salesman, waktu pengiriman dan proses pengiriman adalah poin Salesman menanyakan penggunaan dan kebutuhan mobil turun dari 96,67 menjadi 95,24 poin, Salesman mengantarkan mobil kepada konsumen turun dari 96,67 menjadi 90,48 poin, Jumlah bahan bakar yang layak turun dari 96,67 menjadi 95,42 poin, Dihubungi dealer 3 hari setelah proses pengiriman/pengantaran turun dari 53,33 turun menjadi 47,62 poin, dan terakhir Mendapatkan penjelasan cakupan garansi turun dari 86,67 menjadi 85,71 poin. 


\section{Net Promotion Score (NPS)}

Berdasarkan hasil penelitian Skor NPS Dealer dan NPS Merek Suzuki mendapatkan hasil positif - Indikasi potensi perusahaan akan terus bertahan dan tumbuh. Konsumen Suzuki yang akan merekomendasikan dealer dan merek lebih besar dibandingkan detraktornya sehingga membantu Suzuki dalam usaha berkomunikasi dengan konsumen potensial. Dalam NPS suzuki memandang 3 kriteria konsumen setelah dilakukan penelitian wawancara yaitu a. Defractor adalah konsumen akan merekomendasikan tentang keburukan Suzuki kepada keluarga, rekanan dan sekelilingnya apabila akan membeli suzuki, b. Passive maksudnya adalah konsumen tidak akan merekomendasikan terhadap siapa siapa terhadap pembelian suzuki, c. Promoter adalah akan merekomendasikan kembali kepada keluarga, rekanan dan sekeliling terhadap pembelian suzuki

Gambar 4.8

Net Promotion Score (NPS) Kalimantan Timur W3
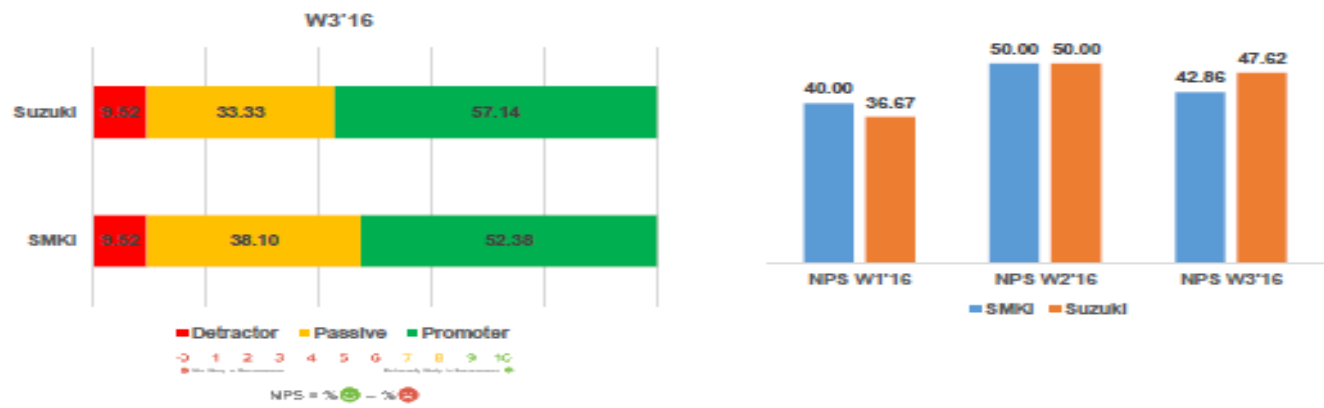

Berdasarkan hasil penelitan di wave 32016 menunjukkan 57,14 persen konsumen akan merekomendasikan kembali pembelian suzuki ke orang lain dan 52,38\% menyarankan untuk membeli di SMKi Kalimantan Timur, akan tetapi konsumen pasive masih sangat tinggi diatas $33 \%$ dan ini menjadi pekerjaan besar suzuki kalimantan timur meningkatkan kepuasan pelanggannya sehingga konsumen ekan merekomendasikan kembali pembelian suzuki. Untuk angka defractor $9,52 \%$ ini masih sangat tinggi perlu ditingkatkan kembali kualitas pelayanan suzuki. 


\section{Share Loyalitas}

Loyalitas adalah cara perilaku pelanggan di masa depan diwujudkan oleh pembelian berulang dan referensi positif kepada lingkungan sekitar. Berdasarkan hasil untuk Skor loyalitas pelanggan Suzuki mengalami trend kenaikan dari Wave 2 ke Wave 3, Skor loyalitas pelanggan Suzuki dealer Samekarindo Indah wave 3 2016 adalah 380 penelitian

Gambar 4.9

Share Loyalitas Kalimantan Timur W3

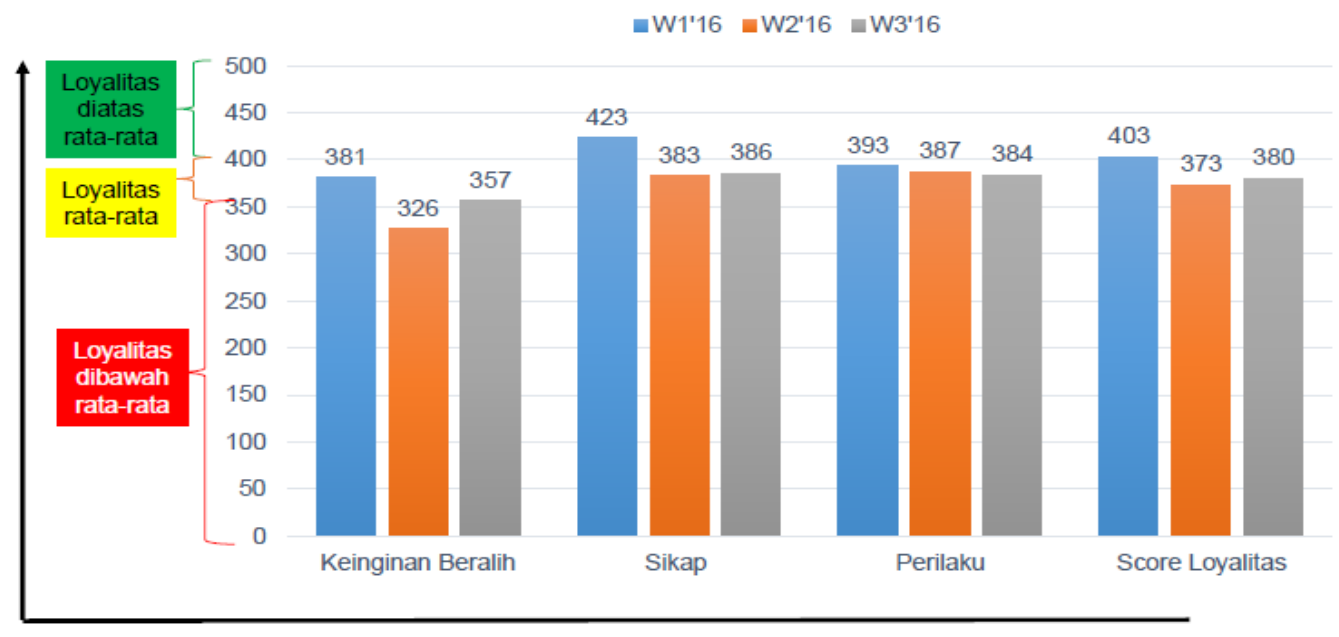

Dari Grafik menunjukkan bahwa Ada 3 ukuran dari loyalitas konsumen yaitu:

1. Untuk konsumen loyalitas di bawah memiliki range 350 poin kebawah

2. Loyalitas rata rata di antara $350-400$ poin

3. Loyalitas diatas rata rata 400-500 poin

Dari data hasil penelitian di wave 1,2 dan 3 menunjukkan konsumen yang memiliki keinginan beralih terdapat di Wave 2 sebab nilai dibawah 350 poin sedangkan di wave 3 masih berada di loyalitas rata rata saja, kemudian mengenai sikap konsumen menunjukkan di semua wave konsumen memiliki loyalitas diatas rata rata, untuk perilaku konsumen di semua wave juga memiliki perilaku diatas rata rata, dari hasil ini maka di simpulkan tingkat loyalitas konsumen terhadap 
pembelian suzuki di semua wave memiliki loyalitas diatas rata rata $\mathrm{W} 1,403$, W2 373 dan W3 380.

\section{KESIMPULAN DAN SARAN}

\section{Kesimpulan}

Prioritas dari Improvement Performance Analysis Suzuki Kalimantan Timur terhadap hasil survey yang dilakukan di Wave 3 maka dapat disimpulkan dalam skala prioritas berikut

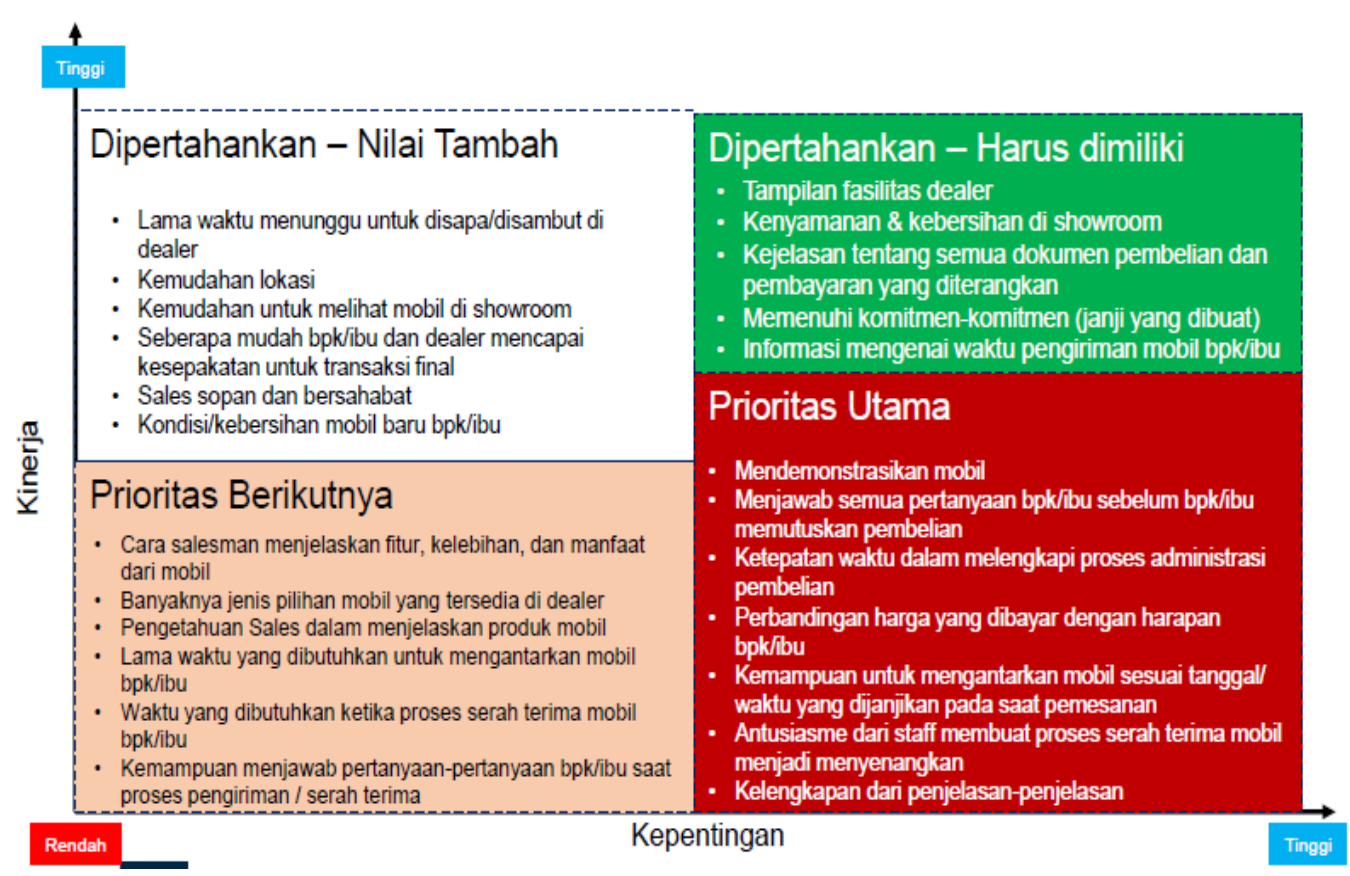

\section{Saran}

Disarankan perusahaan memperhatikan beberapa hal dalam prioritas utama sebab memiliki tingkat kepentingan yang sangat tinggi akan tetapi kinerjanya rendah, hal ini sebaiknya diperhatikan di wave selanjutnya sehingga tercipta kepuasan pelanggan yang baik terhadap pembelian Suzuki Kalimantan timur. Adapun prioritas utama itu adalah

- Mendemonstrasikan mobil

- Menjawab semua pertanyaan bpk/ibu sebelum bpk/ibu memutuskan pembelian

- Ketepatan waktu dalam melengkapi proses administrasi pembelian 
- Perbandingan harga yang dibayar dengan harapan bpk/ibu

- Kemampuan untuk mengantarkan mobil sesuai tanggal/waktu yang dijanjikan pada saat pemesanan

- Antusiasme dari staff membuat proses serah terima mobil menjadi menyenangkan

- Kelengkapan dari penjelasan-penjelasan

\section{DAFTAR PUSTAKA}

Husain Umar. 2005.Manajemen Riset dan Perilaku Konsumen. PT. Gramedia Pusat: Jakarta

Husein Umar. 2002. "Riset Pemasaran dan Perilaku Konsumen". Cetakan kedua.Gramedia. Pustaka Utama, Jakarta.

Kotler Philip dan Amstrong, 2001,Prinsip-Prinsip Manajemen, Jilid 1 Edisi Kedelapan, ah Bahasa Oleh Damos Sihombing, MBA., Penerbit Erlangga, Jakarta.

Kotler, Philip. 1994. Marketing management: Analysis,Planing,Implementation, Control. Ed. 8, New jersey: Prentice Hall, Inc.

Kotler, Philip. 2002. Manajemen Pemasaran (terjemahan), Edisi Millenium,jilid 1. Jakarta : PT. Prenhallindo.

Marimin, 2005, Teknik dan Aplikasi Pengambilan Keputusan Kriteria Majemuk, Cetakan Kedua, Grasindo, Bandung.

Mowen. 1995. Perilaku Konsumen dan Komunikasi Pemasaran, Jakarta.:karangan Sutisna. 